\title{
Impact of Demographic Features of Young Entrepreneurs on Financial Literacy: Meta-Analysis in Delhi NCR
}

\author{
Ankur Agrawal $^{1}$, Mohammad Rumzi Tausif ${ }^{2}$, Praveen Kumar Pandey ${ }^{1} \&$ Prashant Kumar Pandey $^{3}$ \\ ${ }^{1}$ School of Business Studies, Sharda University, Greater Noida, India \\ ${ }^{2}$ College of Business Administration, Prince Sattam Bin Abdulaziz University, Al Kharj, Kingdom of Saudi Arabia \\ ${ }^{3}$ Amity International Business School, Amity University, Noida, India \\ Correspondence: Praveen Kumar Pandey, Management Professional, MBA in Marketing and HR, School of \\ Business Studies, Sharda University, Greater Noida, 201310, India.
}

Received: September 15, 2020

Accepted: November 5, 2020

Online Published: December 10, 2020

doi:10.5430/rwe.v11n6p213

URL: https://doi.org/10.5430/rwe.v11n6p213

\begin{abstract}
Financial literacy capability impacts individuals, families, financial institutions and the economy, as a whole. Financial knowledge is required in every aspect of life in this competitive world. The fundamental object for this analysis is to assess the impact of demographic features of budding young entrepreneurs on their financial Literacy, in the national capital reason of India. The methodology used is, the self-administered and closed-ended questions to collect the experiential data from the young entrepreneurs. Before conducting the survey, dense literature was conducted to understand the background of the concept and to find the research gap. The study reports that a young male budding entrepreneur in the age group of the '20s, started a venture or entrepreneurial activity at an early age and graduate in the field of technology, accounts, economics or management is well versed in understanding the financial implications. The socio-economic culture of India supports the results. The outcome of the study will be useful for the banks, financial institutions, venture capitalist, who involved in financing the start-ups and new ventures moreover, it is also essential for government and policymakers who gives subsidies and other support to make India as a self-reliant nation "Aatm - Nirbhar Bharat".
\end{abstract}

Keywords: financial literacy, gender gap, education, age, young entrepreneurship

JEL Classification: I20, I25

\section{Introduction}

Financial Literacy, which is acquirable, has not been a focal point of the study up until now; however, there is motivation to expect that it assumes a job for enterprising movement. Other than non-econometric and non-financial reasons, other significant components of why organizations come up short are poor financial administration, absence of capital, or misjudgment of dangers. People who are thinking about going into independent work likely know about the presence of exceptional difficulties and dangers of their own business. On the occasion that individuals are uncertain about their ability to manage those challenges and to manage a business, they might need to fill in as an agent.

The 2006 'Global Entrepreneurship Monitor Report uncovered', nonetheless, that low financial literacy proficiency and lacking administration practices limit 'entrepreneurial' innovative movement (Bosma and Harding, 2006). Furthermore, according to a global survey by Standard \& Poor's Financial Services LLC (S\&P), under 25\% of grown-ups are financially literate in South Asian nations (Sud, 2017). For an average Indian, financially literate is a proficiency that is yet to turn into a need. India is home to $17.5 \%$ of the total populace, yet about $76 \%$ of its grown-up populace does not see even the fundamental financially concepts (Sud, 2017). This deficiency means that the youths of India have less financial knowledge than that of other foreign countries.

Moreover, the data related to the distribution of financially literate youths inside the geographical area of India is all the way uncertain and unchecked. This specific scenario is indicating a gap which means that there is a need to study the financial literacy level of young aspiring entrepreneurs. Financial Literacy will provide the potential to better manage their entrepreneurial activities in the future course of action. Based on this, the objectives are being framed. 
A few researchers uncover that entrepreneurs vary in character qualities or inclinations of utilized individuals. Be that as it may, most attributes as the Big Five-character qualities, explicit character attributes, or risk dispositions, which all are affecting natural potential, are named generally stable after some time and along these lines are out of control for policymakers (Caliendo et al., 2013; Cobb-Clark and Schurer, 2012a; 2012b). Therefore, this study objected to analyze the effect of quantifiable attributes of the young entrepreneurs on the financial literacy constituents.

\section{Literature Review}

'Entrepreneur', got from the French activity word "entreprende", and the German word "Unternehmen", was initiated by the French Economist, Richard Cantillon in the mid-eighteenth century. These words mean "to endeavour" (Cunningham and Lischeron, 1991; Afonja, 1999; Anderson et al., 2004; Hisrich and Peters, 1995). In Cantillon's view, an entrepreneur' is a person who buys at direct expenses and sells at too independent expenses (Casson, 1993; Barreto, 1989). This conglomerated functional definition states the essential revolvement around the segment of hazard taking and decisions about asset distribution as a resource. The words, for example, "entrepreneur'", "risk persister", "pioneer experimenter", and so on are reciprocally utilized for entrepreneur'.

Say (1803) utilized the term to allude to individuals who adds-up some incentive in an economy by moving resources from zones of low profitability to territories of higher productivity. He contended further that the entrepreneurs' visionary must have specialized knowledge and judgment with the goal that he must be constantly aware of the expenses and costs of his products and have the option to decide how to think about circumstances for the opportunity. Mill (1848), based upon Say's (1803) definition, explained it by fusing a "management" part to it. He portrayed an entrepreneur as a business visionary who expect the danger of a business adventure along with its management.

Marshall (1890) built up the term entrepreneur further by consolidating the "resources" part of Say and the "management" segment from Mills. In the 20th century, the possibility of a business visionary assumed by an entrepreneur as an "innovator" which was built up by the famous market analyst, Schumpeter (1934). He characterized an entrepreneur as a trailblazer who creates untried innovation. This probabilistic approach places accentuation on advancement in the adversity of new consequences, new generation technicalities, new place analysis, or new formation of the organization. He elucidated that wealth is an outcome of a situation where pragmatic results evolves in the generation of advancement in demand.

From that point onward, an expanding number of researchers and diverse disciplines, for example, ethnology (Stewart, 1991), financial econometrics (Kirchoff, 1991; Bagshawe, 1995; Nafziger and Terrell, 1996, Nafziger, 2006; Hisrich and Peters, 1995), managerial artefacts (Drucker, 1994; Stevenson et al., 1989), psychological scientific work (Shaver and Scott, 1991), social science (Reynolds, 1991), and technological innovation (Reynolds et al., 1999) have explored the idea of entrepreneurial work analysis on the proficient work order in quantum productivity. Further, Bagshawe (1995) characterized an entrepreneur as "an individual who can explore conveniently, recognize development opportunities, assemble resources, and actualize activities to expand those opportunities.

It broadly acknowledges that most customers come up short on financial education, i.e., financial literacy, which is essential to settle on a significant financial decision in their eventual benefits (Braunstein and Welch, 2002; Perry, 2008). Specialists additionally, for the most part, concur that financial knowledge gives off an impression of being legitimately related to self-helpful financial behaviour (Hilgert et al., 2003). Noctor et al. (1992) characterized financial literacy as: "the capacity to settle on educated decisions and choices with respect to the utilization and the executives of cash".

As indicated by the US Financial Literacy and Education Commission, Financial Literacy is "the capacity to make educated decisions and to take successful activities in regards to the present and future use and the board of cash" (Basu, 2005). The Organization for Economic Cooperation and Development (OECD, 2005) characterizes monetary literacy as- "the blend of consumers'/investors" comprehension of financial products, ideas, and their capacity and certainty to acknowledge financial risk and openings, to settle on financial risks and opportunities, to realize where to go for assistance and to take other compelling activities to improve their financial prosperity."

These definitions propose that financial literacy proficiency incorporates increments in financial knowledge or skills and changes in financial behaviour (Hilgert et al., 2003; Mandell, 2004). Financial literacy influences people, family units, financial organizations, and the more extensive economy since it is a vital piece of our everyday lives and its absence has been referred to by numerous observers as a noteworthy explanation behind falling sparing rates (Hilgert et al., 2003), mounting buyer obligation (Stango and Zinman, 2007), (Lusardi and Mitchell, 2006; 2007), the reason for divorce, psychological instability, and an assortment of other despondent encounters (Cleek and Pearson, 1985; Kinnunen and Pulkkinen, 1998), the reason for intense pressure, wretchedness, and lower confidence (Wolcott and 
Hughes, 1999), and low profitability in the work environment (Fletcher et al., 1997; Joo and Grable, 2000; Welsch, 1992).

Miller et al. (2009) and Glaser and Walther (2013) find out that financial literacy is significant for a few reasons. Financial literacy can help in planning consumers (and organizations) for extreme budgetary occasions, by promoting methodologies that moderate risk, for example, aggregating reserve funds, broadening resources, and obtaining protection. Financial literacy likewise improves conduct, for example, the shirking of over-indebtedness. Financial literacy is responsible for viable cash management. Bruhn and Zia (2011) examined the effect of the 'financial literacy' program on firm results of youthful entrepreneurs who kept their eyes on business visionaries. Andoh and Nunoo (2011) find that the literacy of proprietors of SMEs is a significant factor in clarifying the usage of financial administrations by SMEs.

Squat degrees of financial literacy can avert new-ventures from comprehension and evaluating 'financial items' from financial institutions. The Association of Chartered Certified Accountants (2014) pins out of which the difficulties confronting financial institutions are the most part squat degree of 'financial-awareness' among entrepreneurs. Wise (2013) finds that increments in financial-literacy prompt progressively visits and creation of fiscal statements. An entrepreneur that produces fiscal statements as often as possible has a higher probability of credit reimbursement and a lower probability of deliberately close his/her business. As indicated by Kotzè and Smit (2008), the absence of individual financial literacy impacts contrarily on the financial statements of new pursuits and can prompt potential disappointments of SMEs (Sucuahi. 2013).

Researches exhibit that financially educated individuals will undoubtedly have proper credits, a higher pointlessness of unspent pay, higher paces of return, and are cost-profitable concerning speculation and related reserve funds (Disney and Gathergood, 2013; Jappelli and Padula, 2013; Klapper et al., 2013). Furthermore, financial literacy assets focus on access and instalment of loans creativity. As indicated by Herrington et al. (2009), a decent degree of financial literacy can renovate access to funding proficiency by new pursuits (Wise 2013), lessen the opportunity of a loan-default progression (Kotzè and Smit 2008) and improve sales and corporate business appraisement (Bruhn and Zia 2011).

This shows that financial literacy is not generally acknowledged by most buyers to settle on significant financial choices (Braunstein and Welch, 2002; Perry, 2008). Specialists, likewise, for the most part, concur that financial knowledge of learning seems, by all accounts, to be straightforwardly connected with self-advantageous financial behavioural conduct (Hilgert et al., 2003). These announcements recommend that financial literacy proficiency joins augments in financial knowledge or abilities and changes in the fiscal lead (Hilgert et al., 2003; Mandell, 2004).

Prohibition of females from financial services has been accounted for, by various analyses that have discovered that ladies are more rejected than men both at the firm and individual levels. Studies report that female-dominated firms face more financial constraints more imperatives than male-dominated organizations (for example, Presbitero et al., 2014; Henderson et al., 2015; and Beck et al., 2011).

The gender gap is the worst thing about inclusion in financial incorporation, especially in developing markets and creating economies. Gender divergence is usual in most financial econometrically and socially spheritic. Various related studies propose that all things considered, females gain 10-30 per cent less than men for equivalent work (World Bank, 2012). Internationally, of the 2 billion youths that do not have a financial balance in their bank account, 1.1 billion are females. Late proof recommends that, around the world, 58 per cent of females have a record at a formal financial organization contrasted with 65 per cent of men (Demirguc-Kunt et al. 2015).

In developing nations, the gender gap is comparably unaltered at 9 per cent yet fluctuates crosswise over locales. In South Asia, the financial literacy for gender dissimilarity is exceptionally high at 18 per cent, and in India, it is 20 per cent. Indeed, even in the wake of superintending for a large group of individualistic qualities including pay matrix inculcation, higher education, business status, citizenship and age, gender-gap orientation remains altogether identified with access and utilization of financial-inclusive administrations (Demirguc-Kunt et al. 2013). Neumeyer and Santos (2018) pinout that the influence of demographic characteristics, such as age, is present and is explicit on the performance of the (young) entrepreneurs. So, this study included the age demography into its scope as the ideal age for young entrepreneurs is not yet studied, based on the analysis.

More noteworthy financial literacy levels are found in people with professional levels and more noteworthy access to financial data and its influence on inclusion. This way, Amadeu (2009) pins out that more contact, during undergrad or particular courses, with subjects identified with the fund and financial matters decidedly impacts on the everyday monetary and financial practices. Understudies or the students from the courses of Economics, Administration, and Accounting had a higher monetary learning level. Also, Lusardi and Mitchell (2011) found that people with squat 
educational qualification levels are more averse to address the inquiries accurately and bound to state they do not have any idea about the appropriate response (Chen and Volpe, 1998). Nevertheless, most of the studies did not put their focus on the level of education one should acquire to get a comparative advantage while investing financial resources into a new venture.

Based on the above review of literature, following hypotheses can be formulated for testing:

i. There is a significant impact of education level on the Financial Attitude, Behavior, and Knowledge.

ii. There is a significant impact of age on the Financial Attitude, Behavior, and Knowledge

iii. There is a significant impact of gender on the Financial Attitude, Behavior, and Knowledge

Further, the impact of age, education, and gender on the financial literacy components can further affect the viability of their new prospective venture.

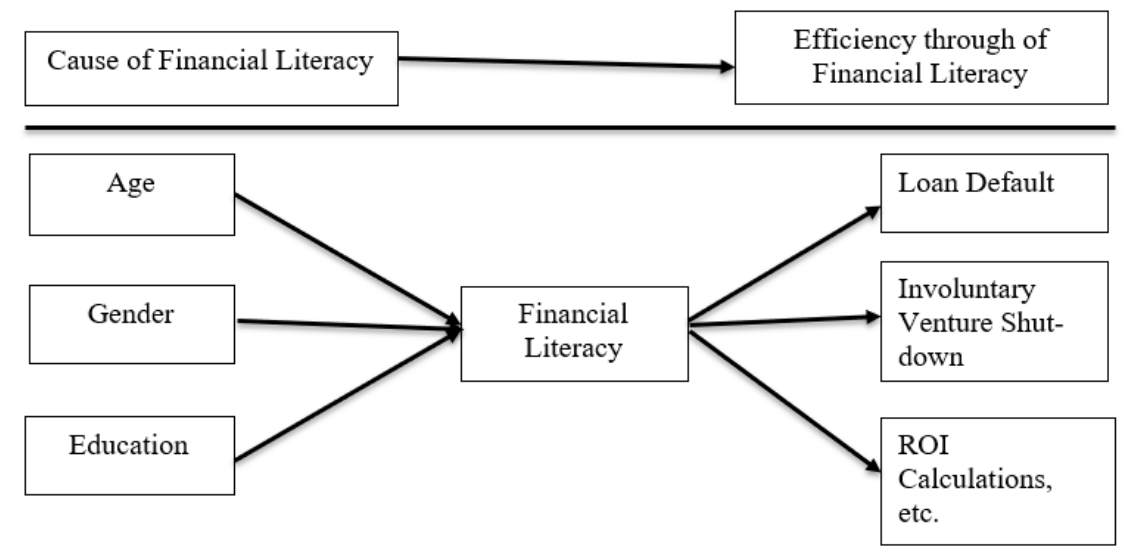

Figure 1. Cause and effect of financial literacy

\section{Aims}

i. To determine the connection between the education level of the entrepreneurs and their level of financial literacy.

ii. To formulate the connection between the orientation of gender and the level of financial literacy.

iii. To determine the relationship between the age and the financial literacy level.

\section{Methods}

The research methodology personified with following stages:

\subsection{Sample and Procedures}

The self-administered and closed-ended questions were added into the questionnaire to collect the experiential data from the young entrepreneurs. The convenience and snowball sampling method has been used for the collection of data. Before the conduct of the survey, the works of literature were studied and analyzed to understand the background. Moreover, in that case, 76 works of literature have been analyzed. The respondents are being selected based on the response they gave to the question: - "Do you have any business idea and are trying to make that into the reality in the coming future?" If they responded "Yes", then only they were asked to fill out the questionnaire, otherwise not. In totality, 412 responses from the young entrepreneurs are collected.

\subsection{Data Analysis}

For content legitimacy, the measures and constructs were embraced from the current scales. All questions, including the demographic questions and financial literacy items, are solicited with Likert scale, implies scoring 1 for strongly disagree and scoring 5 for strongly agree. They develop things that were set up in English for dissemination in the Delhi and National Capital Region (NCR). 


\subsection{Measures}

The analysis of data has been done through IBM SPSS 22.0. The internal consistency reliability is broken down through Cronbach's Alpha analysis. The alpha value is greater than the 0.6 is said to be sufficient to state that information is reliable. The analysis-of-variance (ANOVA) is led to appraise the level of impact of one variable on the other one. Besides, the type of association, i.e., positive or negative ones, is likewise assessed through the coefficient values under the ANOVA and Multivariate-ANOVA (MANOVA). Further, the chi-square test and cross-tabulation is being done to quantify the results.

\begin{tabular}{lll}
\hline Variables & Test Applied \\
\hline \multicolumn{1}{l}{ Gender and Financial Literacy } & \\
\hline$\bullet \quad$ Gender and Financial Behavior & ANOVA \\
\hline$\bullet \quad$ Gender and Financial Attitude & ANOVA \\
\hline$\bullet \quad$ Gender and Financial Knowledge & Cross-Tab \\
\hline Education level and financial literacy & \\
\hline$\bullet \quad$ Education level and Financial Behavior & Chi-Square \\
\hline$\bullet \quad$ Education level and Financial Attitude & Chi-Square \\
\hline$\bullet \quad$ Education level and Financial Knowledge & Cross-Tab \\
\hline Age and financial literacy & \\
\hline$\bullet \quad$ Age and Financial Behavior & MANOVA \\
\hline$\bullet \quad$ Age and Financial Attitude & MANOVA \\
\hline$\bullet \quad$ Age and Financial Knowledge & Cross- Tab \\
\hline
\end{tabular}

Table 1. Internal consistency analysis

\begin{tabular}{ll}
\hline Cronbach's Alpha & N of Items \\
\hline 0.797 & 27 \\
\hline
\end{tabular}

Therefore, after calculation, it can be said that the data is reliable and valid for further analysis (in Table 1).

\section{Results and Discussion}

Table 2. ANOVA (gender and financial literacy)

\begin{tabular}{llllll}
\hline Financial_Behavior & & & & & \\
\hline & SS & df & Mean Square & F & Sig. \\
\hline Between Groups (BG) & 1.398 & 1 & 1.398 & 3.813 & .049 \\
\hline Within Groups (WG) & 150.330 & 410 & .367 & & \\
\hline Total & 151.728 & 411 & & & \\
\hline Financial_Attitude & & & & & .109 \\
\hline BG & .846 & 1 & .846 & \\
\hline WG & 134.303 & 410 & .328 & \\
\hline Total & 135.149 & 411 & & & \\
\hline
\end{tabular}


The gender has an impact on the financial behaviour of the person (as per Table 2). Financial behaviour is the behaviour that the person shows while managing personal finances. Through the results, it can be said that the different genders show different behaviour while finance management.

The gender has no impact on the financial attitude of the person (as per Table 2). Financial attitude alludes to the opinion and the judgment of any individual towards the finances. The results show that gender does not act as a basis for differentiation in the financial attitude of them.

Table 3. Cross-tabulation (FK vs. Gender)

\begin{tabular}{llll}
\hline & & Gender & \\
\cline { 3 - 4 } & & Male & Female \\
\hline FK1 & Correct Option & 147 & 145 \\
\hline FK2 & Correct Option & 135 & 104 \\
\hline FK3 & Correct Option & 126 & 106 \\
\hline FK4 & Correct Option & 139 & 127 \\
\hline FK5 & Correct Option & 136 & 112 \\
\hline FK6 & Correct Option & 136 & 121 \\
\hline FK7 & Correct Option & 140 & 139 \\
\hline FK8 & Correct Option & 136 & 140 \\
\hline FK9 & Correct Option & 148 & 133 \\
\hline
\end{tabular}

Table 3 depicts that males have a comparatively better knowledge of financial concepts and calculations. However, also, it can be interpreted as both genders have approximately similar levels of financial knowledge. This means that financial terminologies are better known to both genders. Nevertheless, some of the entrepreneurs still do not have basic knowledge of financial terms.

Table 4. Chi-square tests (education level and financial literacy)

\begin{tabular}{llll}
\hline Financial Behavior & & & \\
\hline Pearson Method & Value & df & Sig. value \\
\hline Financial Attitude & 107.715 & 78 & .015 \\
\hline Pearson Method & & & \\
\hline
\end{tabular}

The education qualification also impacts the financial behaviour of the person (Table 4). Financial behaviour is the behaviour that the person shows while managing personal finances. The education qualification has an impact on the financial attitude of the person (table 4). Financial attitude alludes to the opinion and the judgment of any individual towards the finances. 
Table 5. Crosstab (FK vs. Education)

\begin{tabular}{llllll}
\hline & & \multicolumn{2}{l}{ Pursuing Degree } & \\
\cline { 3 - 6 } & & Bachelors & Masters & Doctorate & Post-Doc. \\
\hline FK1 & Correct Option & 50 & 149 & 86 & 7 \\
\hline FK2 & Correct Option & 42 & 118 & 75 & 4 \\
\hline FK3 & Correct Option & 43 & 118 & 69 & 2 \\
\hline FK4 & Correct Option & 52 & 122 & 87 & 5 \\
\hline FK5 & Correct Option & 47 & 122 & 77 & 4 \\
\hline FK6 & Correct Option & 47 & 119 & 87 & 6 \\
\hline FK7 & Correct Option & 49 & 133 & 91 & 4 \\
\hline FK8 & Correct Option & 53 & 137 & 82 & 4 \\
\hline FK9 & Correct Option & 51 & 137 & 89 & 4 \\
\hline
\end{tabular}

Table 5 depicts that the entrepreneurial candidate who has qualified their Masters have better financial knowledge if compared to other qualifications. The entrepreneurs whom all have completed their post-graduation degree better understand the financial concepts and their applications. Also, most of the respondents responded correctly had studied economic subjects, such as statistics, cost accounting, econometrics, entrepreneurship, and related subjects. This finding confirms the findings of Amadeu (2009) and Lindh and Thorgren (2016) but in the Indian context.

Table 6. Tests of between-subjects effects (age and financial literacy)

\begin{tabular}{llllll}
\hline D.V.: Financial Behaviour & $\begin{array}{l}\text { Type III Sum of } \\
\text { Squares }\end{array}$ & $\mathrm{df}$ & Mean Square & F & Sig. \\
\hline Corrected Model & $7.036^{\mathrm{a}}$ & 4 & 1.759 & 4.948 & .001 \\
\hline Intercept & 3132.184 & 1 & 3132.184 & 8810.465 & .000 \\
\hline Age in Years & 7.036 & 4 & 1.759 & 4.948 & .001 \\
\hline Error & 144.691 & 407 & .356 & & \\
\hline Total & 6028.272 & 412 & & & \\
\hline Corrected Total & 151.728 & 411 & & & \\
\hline D.V.: Financial Attitude & $3.616^{\mathrm{a}}$ & 4 & .904 & \\
\hline Corrected Model & 3098.313 & 1 & 3098.313 & .026 \\
\hline Intercept & 3.616 & 4 & .904 & .000 \\
\hline Age in Years & 131.533 & 407 & .323 & \\
\hline Error & 6031.852 & 412 & & & \\
\hline Total & 135.149 & 411 & & & \\
\hline Corrected Total & & & & & \\
\hline
\end{tabular}

The age also impacts the financial behaviour of the person (Table 6). Financial behaviour is the behaviour that the person shows while managing personal finances. Through the results, it can be said that the age of the entrepreneur does not determine the behaviour towards finance management of the individual.

The age also impacts the financial attitude of the person (Table 6). Financial attitude alludes to the opinion and the judgment of any individual towards the finances. The results show that the educational qualification does not act as a basis for differentiation in the financial attitude of them. 
Table 7. Crosstab (FK vs Age)

\begin{tabular}{lllllll}
\hline & & \multicolumn{2}{l}{ Age (in Years): } & & \\
\cline { 3 - 7 } & & Below 18 & $18-20$ & $21-24$ & $25-29$ & Above 30 \\
\hline FK1 & Correct Option & 50 & 12 & 108 & 64 & 58 \\
\hline FK2 & Correct Option & 38 & 8 & 97 & 53 & 43 \\
\hline FK3 & Correct Option & 40 & 10 & 85 & 52 & 45 \\
\hline FK4 & Correct Option & 48 & 10 & 93 & 61 & 54 \\
\hline FK5 & Correct Option & 44 & 10 & 89 & 56 & 49 \\
\hline FK6 & Correct Option & 54 & 6 & 88 & 52 & 57 \\
\hline FK7 & Correct Option & 52 & 13 & 94 & 58 & 62 \\
\hline FK8 & Correct Option & 53 & 9 & 92 & 56 & 66 \\
\hline FK9 & Correct Option & 45 & 9 & 101 & 55 & 71 \\
\hline
\end{tabular}

Table 7 depicts that the age group of 20-24 has higher quality comprehension of the financial conceptual perseverance and calculative programming structure. This age group of entrepreneurs showed a better understanding of the financial concepts.

\section{Conclusion}

The financial decision-making ability is dependent on the financial literacy level of the candidate. So, the high literacy level will take care of the well-being of businesses and households. Therefore, the objective of this study is set to gauge the literacy level of entrepreneurial candidates. These are the candidates who all have intense aspirations to innovate something new to change the scenario of the society. Related to that, the findings are shown in a detailed manner as follows:

As per the preliminary analysis, gender has its impact on financial behavior only and not on the financial attitude. In the case of financial knowledge, the males have a comparatively better knowledge of financial terms and calculations if compared to the females. The difference between both is very minute and can be said as competitive knowledgeability. Furthermore, it is found that educational qualifications have a direct impression on financial-behavior and attitude. The post-graduates have a better knowledge of the financial terms and concepts.

Finally, age is found to be the determining factor for financial behavior and attitude. And the candidates belonging to the age group of 20-24 have a greater understanding of the financial terms and calculations. Such findings affirm the pressing requirement for contriving viable activities to limit the financial illiteracy issue. The subjects such as economics, accounts, entrepreneurship, etc. have their significant effect on the financial literacy level and further the entrepreneurial skills are positively associated. One of the potential measures to be taken alludes to the consideration of subjects in regards to financial management, market finance, and entrepreneurship in all undergraduate and postgraduate courses, paying little attention to the learning field. Also, the another potential measure concerns the creation and reception of instructive projects, which ought to advance individual financial literacy in all segments of society, yet with activities and explicit substances that are recognized by each group's profile.

The identified gap was that there is a need to study the financial literacy level of the youths of the Delhi \& NCR region. This study incorporates the young entrepreneurs, their quantifiable attributes, and financial literacy attributes. This paper is a pioneer by incorporating a few factors in a solitary model, permitting the distinguishing proof of the effect of factors and building up significance orders. From the institute's perspective, the principal concentrate so far has been independently recognizing the pretended by socio-econometric and demographic and psychographic factorial analysis on financial literacy for the proficiency.

The implication of this analysis for the research is dependent upon certain limitations, for example, the selection of factors and the method of their strategy. Different scales may be formulated and tried as financial literacy indicators. As it is dependent on an overview research structure and cross-section data for the information, the strategy sets limits for tending to the autonomous issuance characterization. So, further, in the future, the studies can be conducted with variables such as family background, economic surroundings, and other variables. 


\section{Author Contributions}

Conceptualization - Dr. Ankur Agrawal, Praveen Kumar Pandey

Data curation - Dr Ankur Agrawal, Dr. Mohammad Rumzi Tausif, Praveen Kumar Pandey, Prashant Kumar Pandey

Investigation - Praveen Kumar Pandey, Prashant Kumar Pandey

Methodology - Praveen Kumar Pandey, Prashant Kumar Pandey, Dr Ankur Agrawal

Project administration - Dr Ankur Agrawal, Prashant Kumar Pandey

Supervision - Dr Ankur Agrawal, Dr. Mohammad Rumzi Tausif

Validation - Dr Ankur Agrawal, Dr. Mohammad Rumzi Tausif, Praveen Kumar Pandey

Writing - Prashant Kumar Pandey, Praveen Kumar Pandey, Dr Ankur Agrawal, Dr. Mohammad Rumzi Tausif

\section{Acknowledgement}

The authors of this study declare that they have not got any fund assistance to execute this study from any institution, so there is no conflict of interest between the authors of the study. Also, there is no financial interest and non- financial interest hidden in the publication of this manuscript.

\section{References}

Afonja, A. A. (1999). Entrepreneurship education and enterprises culture: lessons from other countries. Proceedings of the National Conference on Entrepreneurship Education in Nigeria Tertiary Institutions NDE/CIRD, O.A.U., Ile Ife (pp. 20-54).

Amadeu, J. R. (2009). A educação financeira e sua influência nas decisões de consumo e investimento: proposta de inserção da disciplina na matriz curricular Dissertação de mestrado. Universidade do Oeste Paulista, São Paulo, SP, Brasil.

Anderson, S. G., Zhan, M., \& Scott, J. (2004). Targeting financial management training at low income audiences. Journal of Consumer Affairs, 38(1), 167-77. https://doi.org/10.1111/j.1745-6606.2004.tb00470.x

Andoh, F. K., \& Nunoo, J. (2011). Sustaining small and medium enterprises through financial service utilization: does financial literacy matter?.

Association of Chartered Certified Accountants. (2014). Financial education for entrepreneurs: what next?. Retrieved September 15, 2019, from https://www.accaglobal.com/content/dam/acca/global/PDF-technical/small-business/pol-tp-fefe.pdf

Bagshawe, P. (1995). Viva South African entrepreneurs-success from humble beginnings. Lifespan Publications, Durban.

Barreto, H. (1989). The entrepreneur in microeconomic theory: disappearance and explanation. Routledge, London.

Basu, S. (2005). Financial literacy and the life cycle, financial planning association. Washington, DC.

Beck, T., Behr, P., \& Madestam, A. (2011). Sex and credit: Is there a gender bias in lending?. European Banking Center Discussion Paper. https://doi.org/10.2139/ssrn.1923649

Bosma, N., \& Harding, R. (2006). Global Entrepreneurship Monitor (GEM) 2006 Report. Babson College and London Business School, London.

Braunstein, S., \& Welch, C. (2002). Financial literacy: an overview of practice, research, and policy. Federal Reserve Bulletin, 88, 445-457. Retrieved from www.federalreserve.gov/pubs/bulletin/2002/1102lead.pdf

Bruhn, M., \& Zia, B. (2011). Stimulating managerial capital in emerging markets: the impact of business and financial literacy for young entrepreneurs. World Bank Working Paper, 5642. https://doi.org/10.1596/1813-9450-5642

Caliendo, M., Fossen, F., \& Kritikos, A. S. (2013). Personality characteristics and the decisions to become and stay self-employed. Small Business Economics, 42(4), 787-814. https://doi.org/10.1007/s11187-013-9514-8

Casson, M. (1993). The entrepreneurs: an economic theory. Martin Robinson, Oxford.

Chen, H., \& Volpe, R. P. (1998). An analysis of personal financial literacy among college students. Financial Services Review, 7(2), 107-128. https://doi.org/10.1016/S1057-0810(99)80006-7

Cleek, M. G., \& Pearson, T. A. (1985). Perceived causes of divorce: an analysis of interrelationships. Journal of Marriage and the Family, 47(1), 179-183. https://doi.org/10.2307/352080 
Cobb-Clark, D. A., \& Stefanie, S. (2012a). The Stability of Big-Five Personality Traits. Economics Letters, 115(1), 11-15. https://doi.org/10.1016/j.econlet.2011.11.015

Cobb-Clark, D. A., \& Stefanie, S. (2012b). Two economists' musings on the stability of locus of control. The Economic Journal, 123(570), F358-F400. https://doi.org/10.1111/ecoj.12069

Cunningham, J. B., \& Lischeron, J. (1991). Defining entrepreneurship. Journal of Small Business Management, 29 , 45-59.

Demirguc-Kunt, A., \& Klapper, L. (2013). Measuring financial inclusion: Explaining variation in use of financial services across and within countries. Brookings Papers on Economic Activity, 2013(1), 279-340. https://doi.org/10.1353/eca.2013.0002

Demirguc-Kunt, A., Klapper, L., Van Oudheusden, P., \& Zingales, L. (2015). Trust in Banks. Working paper. Washington: Development Research Group, World Bank.

Drucker, P. F. (1994). Innovation and entrepreneurship: practice and principles. Butterworth Heineman, Oxford.

Fletcher, C. N., Beebout, G., \& Mendenhall, S. (1997). Developing and evaluating personal finance education at the worksite: a case study. Personal Finances and Worker Productivity, 1(1), 54-59.

Glaser, M., \& Walther, T. (2013). Run, walk, or buy? financial literacy, dual-process theory, and investment behavior. Working paper. https://doi.org/10.2139/ssrn.2336109

Henderson, L., Herring, C., Horton, H. D., \& Thomas, M. (2015). Credit Where Credit is Due? Race, Gender, and Discrimination in the Credit Scores of Business Startups. The Review of Black Political Economy, 42(4), 459-479. https://doi.org/10.1007/s12114-015-9215-4

Herrington, M., Kew, J., \& Kew, P. (2009). Global entrepreneurship monitor, South African report. Retrieved September 15, 2019, from https://www.gemconsortium.org/report/gem-south-africa-2016-2017-report

Hilgert, M. A., Hogarth, J. M., \& Beverly, S. G. (2003). Household financial management: The connection between knowledge and behavior. Federal Reserve Bulletin, 89, 309-322.

Hisrich, R. D., \& Peters, M. P. (1995). Entrepreneurship: starting, developing, and managing a new enterprise (3rd ed.). Irwin McGraw-Hill, Boston, MA.

Joo, S., \& Grable, J. E. (2000). Improving employee productivity: the role of financial counselling and education. Journal of Employment Counselling, 37, 2-15. https://doi.org/10.1002/j.2161-1920.2000.tb01022.x

Kinnunen, U., \& Pulkkinen, L. (1998). Linking economic stress to marital quality among finish marital couples. Journal of Family Issues, 19(6), 705-724. https://doi.org/10.1177/019251398019006003

Kirchoff, B. A. (1991). The effect of firm formation and growth on job location in the USA. Journal of Business Venturing, 3, 261-272. https://doi.org/10.1016/0883-9026(88)90008-0

Kotzè, L., \& Smit, A. (2008). Personal financial literacy and personal debt management: the potential relationships with new venture creation. South African Journal of Entrepreneurship and Small Business Management, 1(1), 35-50. https://doi.org/10.4102/sajesbm.v1i1.11

Leora, K., Annamaria, L., \& Panos, G. A. (2013). Financial literacy and its consequences: Evidence from Russia during the financial crisis. Journal of Banking \& Finance, 37(10), 3904-3923. https://doi.org/10.1016/j.jbankfin.2013.07.014

Lindh, I., \& Thorgren, S. (2016). Entrepreneurship education: The role of local business. Entrepreneurship \& Regional Development, 28(5-6), 313-336. https://doi.org/10.1080/08985626.2015.1134678

Lusardi, A., \& Mitchell, O. S. (2006). Financial literacy and planning: implications for retirement wellbeing. Working paper, Pension Research Council, Wharton School, University of Pennsylvania, Philadelphia, PA.

Lusardi, A., \& Mitchell, O. S. (2007). Financial literacy and retirement preparedness: Evidence and implications for financial education. Business Economics, 42, 35-44. https://doi.org/10.2145/20070104

Lusardi, A., \& Mitchell, O. S. (2011). Financial literacy and retirement planning in the United States. Journal of Pension Economics and Finance, 10(4), 509-525. https://doi.org/10.1017/S147474721100045X

Mandell, L. (2004). Financial literacy: Are we improving? Results of the 2004 national JumpStart survey. Washington, DC: Jumpstart Coalition.

Marshall, A. (1890). Principles of economics (8th ed.). Macmillan, London. 
Mill, J. S. (1848). Principles of political economy. Great Mind, London.

Miller, M. (2009). (World Bank) - “Access Finance” issue No. 27 - A news letter. The Financial and Private sector.

Nafziger, E. W. (2006). Economic development (4th ed.). Cambridge University Press, Cambridge.

Nafziger, E. W., \& Terrell, D. (1996). Entrepreneurial human capital and the long-run survival of firms in India. World Development, 24(4), 689-96. https://doi.org/10.1016/0305-750X(95)00161-5

Neumeyer, X., \& Santos, S. C. (2018). Sustainable business models, venture typologies, and entrepreneurial ecosystems: A social network perspective. Journal of Cleaner Production, 172, 4565-4579. https://doi.org/10.1016/j.jclepro.2017.08.216

Noctor, M., Stoney, S., \& Stradling, R. (1992). Financial literacy: a discussion of concepts and competencies of financial literacy and opportunities for its introduction into young people's learning. National Foundation for Education Research, London.

OECD. (2005). Improving Financial Literacy: Analysis of Issues and Policies. OECD, Paris. https://doi.org/10.1787/9789264012578-en

Perry, V. G. (2008). Is ignorance bliss? Consumer accuracy in judgments about credit ratings. The Journal of Consumer Affairs, 42(2), 189-205. https://doi.org/10.1111/j.1745-6606.2008.00104.x

Presbitero, A. F., Rabellotti, R., \& Piras, C. (2014). Barking up the wrong tree? measuring gender gaps in firm's access to finance. The Journal of Development Studies, 50(10), 1430-1444. https://doi.org/10.1080/00220388.2014.940914

Reynolds, P. D. (1991). Sociology and entrepreneurship: concepts and contributions. Entrepreneurship Theory and Practice, 16(2), 47-70. https://doi.org/10.1177/104225879201600205

Reynolds, P. D., Hay, M., \& Camp, M. (1999). Global Entrepreneurship Monitor 1999 Executive Report. Kauffman Centre for Entrepreneurial Leadership at the Ewing Marion Kauffman Foundation, Kansas City, MO.

Richard, D., \& John, G. (2013). Financial literacy and consumer credit portfolios. Journal of Banking \& Finance, 37(7), 2246-2254. https://doi.org/10.1016/j.jbankfin.2013.01.013

Say, J. B. (1803). A treatise on political economy. Lippincott, Grambo, Philadelphia, PA.

Schumpeter, J. (1934). The theory of economic development. Harvard University Press, Cambridge, MA.

Shaver, K. G., \& Scott, L. R. (1991). Person, process, choice the psychology of new venture creation. Entrepreneurship Theory and Practice, 16(2), 23-45. https://doi.org/10.1177/104225879201600204

Stango, V., \& Zinman, J. (2007). Fuzzy math and red ink: when the opportunity cost of consumption is not what it seems. Working paper, Dartmouth College, Hanover.

Stevenson, H. H., Roberts, M. J., \& Grousbeck, H. I. (1989). Business Ventures and the Entrepreneur. Irwin, Homewood, IL.

Stewart, A. (1991). A prospectus on the anthropology of entrepreneurship. Entrepreneurship: Theory and Practice, 16(2), 11-92. https://doi.org/10.1177/104225879201600206

Sucuahi, W. T. (2013). Determinants of financial literacy of micro entrepreneurs in Davao City. International Journal of Accounting Research, 1(1), 44-51. https://doi.org/10.12816/0001127

Sud, R. (2017, June 13). Why India needs to work on financial literacy now more than ever. Retrieved August 9, 2019, from https://www.livemint.com/Opinion/f5xo11OSPqxGWUdaWKVb8J/Why-India-needs-to-work-on-financial-liter acy-now-more-than.html

Tullio, J., \& Mario, P. (2013). Investment in financial literacy and saving decisions. Journal of Banking \& Finance, 37(8), 2779-2792. https://doi.org/10.1016/j.jbankfin.2013.03.019

Welsch, H. (1992). International Entrepreneurship and Small Business Bibliography. De Paul University, Chicago, IL.

Wise, S. (2013). The impact of financial literacy on new venture survival. International Journal of Business and Management, 8(23), 30-39. https://doi.org/10.5539/ijbm.v8n23p30 
Wolcott, I., \& Hughes, J. (1999). Towards understanding the reasons for divorce. Working Paper No. 20, Australian Institute of Family Services, Melbourne.

World Bank. (2012). Global Financial Development Report 2014: Financial Inclusion. Washington, DC: World Bank. https://doi.org/10.1596/9780821399859

\section{Appendix}

\begin{tabular}{|c|c|}
\hline \multicolumn{2}{|c|}{ Financial Knowledge Variables } \\
\hline FK1 & $\begin{array}{l}\text { Assume you had Rs. } 2000 \text { in a bank account and the IR was } 4 \% \text { every year. Following } 1 \text { year, what } \\
\text { amount do you acknowledge you would have in the account that you left the cash in the bank? }\end{array}$ \\
\hline FK2 & $\begin{array}{l}\text { Assume you had Rs. } 2000 \text { in a saving bank account and the IR is } 40 \% \text { every year and you never draw } \\
\text { premium or the money installments. Completing } 2 \text { years, what amount would you have on this } \\
\text { account record altogether? }\end{array}$ \\
\hline FK3 & $\begin{array}{l}\text { Envision that the IR on your savings bank account was } 1 \% \text { every year and expansion was } 2 \% \text { every } \\
\text { year. Completing } 1 \text { year, what amount would you have the option to purchase with the money in this } \\
\text { account? }\end{array}$ \\
\hline FK4 & $\begin{array}{l}\text { Accept that a colleague of yours' acquires Rs. } 10,000 \text { today and his cousin acquires Rs. } 10,000 \text { for } \\
\text { three years from now. Who is more richest due to the legacy? }\end{array}$ \\
\hline FK5 & $\begin{array}{l}\text { Assume that in the year 2018, your salary has tripled and the costs of all products have tripled as } \\
\text { well. In } 2018 \text {, what amount will you have the option to purchase with your salary? }\end{array}$ \\
\hline FK6 & Define net-worth. \\
\hline FK7 & Issuance of shares by a company must be in \\
\hline FK8 & $\begin{array}{l}\text { What do you think merits essential consideration when one needs to contrast the bank to pick the one } \\
\text { must take credit from? }\end{array}$ \\
\hline FK9 & Most chronological perception to purchase the insurance is to \\
\hline
\end{tabular}

\section{Copyrights}

Copyright for this article is retained by the author(s), with first publication rights granted to the journal.

This is an open-access article distributed under the terms and conditions of the Creative Commons Attribution license (http://creativecommons.org/licenses/by/4.0/). 